\title{
The European Energy Policy for 2020-2030 RED II: what future for vegetable oil as a source of bioenergy? ${ }^{\text {is }}$
}

\author{
Philippe Dusser* \\ Ex-AVRIL, Paris, France
}

Received 12 July 2019 - Accepted 2 October 2019

\begin{abstract}
The support for vegetable oils biodiesel is defined by the Renewable Energy Directive (RED). After three years of negotiations, RED II (recast of the 2010-2020 RED I) has been adopted and published in December 2018. RED II sets the framework for the EU renewable energy policy for 2021-2030. Although RED II gives a priority to advanced biofuels and electricity in transport with specific targets and multipliers. For crop-based biofuels as vegetable oil biodiesel, RED II offers the possibility to preserve the current investments by giving the Member States the possibility to cap their consumption at the national 2020 consumption level (plus 1\%) with maximum of $7 \%$. With the idea to cut the link of crop-based biofuels with deforestation, a change of approach on the ILUC issue is introduced by RED II with the definition of "high ILUC-risk feedstocks with a significant expansion on land with high carbon stocks". The high ILUC-risk feedstocks will be capped in each Member State at the 2019 level until 2023, and then progressively eliminated by 2030 . An exemption from these constraints is provided for to low ILUC-risk feedstocks not linked to deforestation - direct or indirect- and identified by a certification granted to additional feedstocks produced either through productivity improvements or from cultivation on abandoned or degraded land. An Implementing Act will further detail by 2021 the conditions of the low ILUC-risk certification. In a Delegated Act published in March 2019, the EU Commission classified the palm oil as the sole high ILUC-risk feedstock with more than $40 \%$ expansion on high carbon stock land ( $v s .8 \%$ for soybean) on the base of the current available data. Nevertheless, there is a certain uncertainty on the final use of palm oil in bioenergy, as the details of the certification of low ILUC-risk feedstocks are unknown before the publication of the Implementing Act (2021), and as the Delegated Act himself will be reviewed in 2021 and 2023.
\end{abstract}

Keywords: Renewable Energy Directive (RED II) / biofuels / biodiesel / indirect land use change (ILUC) / Delegated Act / high ILUC-risk / low ILUC-risk / palm oil / deforestation

Résumé - La politique énergétique européenne pour 2020-2030. RED II: quel avenir pour l'huile végétale comme source d'énergie renouvelable ? Le soutien au biodiesel d'huiles végétales est défini par la Directive sur les énergies renouvelables (RED). Après trois ans de négociations, la Directive RED II, qui prend la suite de RED I (2010-2020) a été adoptée et publiée en décembre 2018. RED II définit le cadre de la politique de l'Union Européenne en matière d'énergie renouvelable pour 2021-2030. RED II affiche une priorité donnée aux biocarburants « avancés » $\left(2^{\mathrm{e}}\right.$ et $3^{\mathrm{e}}$ génération) ainsi qu'à l'électricité dans les transports : ceux-ci bénéficient de soutiens particuliers au travers des objectifs spécifiques et des multiplicateurs permettant de comptabiliser avec un facteur de 2, 3... 4 fois leur incorporation effective au regard des objectifs. En ce qui concerne les biocarburants issus de cultures tel que le biodiesel d'huile végétale, RED II ouvre la possibilité (mais pas la garantie) de préserver les investissements actuels, en plafonnant leur utilisation dans le cadre de plafond nationaux fixés par États membres au niveau de leur consommation 2020 (plus $1 \%$ ) avec un maximum de $7 \%$. RED II renforce la durabilité des biocarburants issus de cultures en organisant l'élimination d'ici 2030 de ceux qui sont liés à la déforestation qui sont définis dans une nouvelle catégorie de matières premières à «haut risque de changement d'affectation des sols indirect» (haut risque de CASI ou high ILUC-risk) dont l'expansion au niveau mondial s'est produite sur des terres à stocks élevés

\footnotetext{
Contribution to Topical Issue "Biodiesel / Biodiesel".

*Correspondence: philippe.dusser@outlook.com
} 
de carbone. Avant leur élimination progressive à partir de 2023 jusqu'en 2030, une période transitoire de 2020 à 2023 prévoit le plafonnement national au niveau de consommation 2019 des matières premières à haut risque de CASI. Une exemption est prévue pour une partie de ces matières premières dans le cadre d'une certification de «faible risque de CASI» (low ILUC-risk). Les matières premières certifiées doivent démontrer qu'elles n'ont pas entrainé de déforestation directe ou indirecte, qu'elles proviennent soit d'une amélioration de la productivité, soit de la culture de terres abandonnées ou dégradées. Un acte d'exécution attendu d'ici 2021, doit clarifier les conditions précises de la certification. Un Acte Délégué de la Commission (mars 2019), a classé la seule huile de palme dans la catégorie haut risque de CASI en raison d'un niveau de plus de $40 \%$ d'expansion sur les terres riches en carbone (contre $8 \%$ pour le soja). Cependant une certaine incertitude demeure sur la manière dont sera effectivement encadrée l'utilisation d'huile de palme dans les biocarburants: elle dépend en effet de l'Acte d'Exécution sur la certification «faible risque-CASI» (2021) et des révisions prévues de l'Acte Délégué, en 2021 et 2023.

Mots clés : Directive sur les énergies renouvelables (RED II) / biocarburants / biodiesel / changement d'utilisation des sols indirect (CASI/ILUC) / Acte Délégué / haut risque de CASI / faible risque de CASI / huile de palme / déforestation

RED II - After a 3 years negotiation, the Directive finally allows the stabilization of the crop-based biofuels consumption for 2021-2030.

The RED II - Directive 2018/2001 on the promotion of the use of energy from renewable sources (recast of the previous Directive (RED I) adopted in late 2008 for the period 2010 to 2020) has been adopted the 11th December 2018 and sets the framework of the renewable energy policy for the period 2021-2030. The Member-States must have transposed the RED II in national legislation by the end of June 21.

The Renewable Energy Directive which defines the policy for biofuels in transport - crucial for the outlet of vegetable oils in Biodiesel- has a much broader perspective as it addresses the use of renewable energy in all sectors: electricity (RES-E), heating and cooling (RES-H\&C), and transport (RES-T).

In the RED II debates, the crop-based biofuels issue has been intensely negotiated by the co-legislators (Parliament and Council):

The original proposal from the Commission (November 2016), only provided targets for "advanced biofuels" and renewable electricity ( $6.8 \%$ of which $3.6 \%$ for advanced). On the contrary, the crop-biofuels already limited since 2015 to a maximum cap of $7 \%$ (ILUC Directive) were to be phased down by half with a country cap of $3.8 \%$ in 2030 (nota: first drafts from the Commission even envisaged a total phase-out of crop-biofuels).

In the EU Council, countries had different approaches: some were very opposed to first generation biofuels, but the majority decided to keep the RED I main framework as amended just two years before by the 2015 "ILUC Directive". The Council's "General approach" of December 2017 provided a specific transport target of $14 \%$ (raising the ambition from the $10 \%$ of the RED I), maintained the crop-biofuels cap at $7 \%$; with regards to advanced biofuels, as most countries found the targets difficult to reach, the Council provided high "multipliers" to reduce the effective obligation.

In the EU Parliament, the negotiation of a position was extremely intense between political groups, as well as complex due to the number of committees involved: two responsible committees (ITRE for the global report and ENVI for the biofuels), and approximately 10 other committees for opinion (among which AGRI):

- The Greens (with MEP Bas Eickhout as rapporteur in the European Parliament's Environment Committee -ENVIresponsible for biofuels) defended extremely negative positions against crop-based biofuels, getting the ENVI
Committee to vote for a total phase-out of crop-based biofuel $(0 \%$ in 2030$)$ and immediate elimination of palm oil as a feedstock in 2021, while providing an accounting of ILUC figures in the GHG balance sheet;

- The MEP supporting EU agriculture in the Parliament, under the lead of the EPP (European People's Party), argued in favor of the biofuels issued from EU agriculture, and fought for an exemption for "highly sustainable cropbased biofuels" defined as co-producing protein, thus mitigating the EU protein deficit;

- The final position of the Parliament (January 2018) retained the concept of a general transport target $(12 \%)$, a compromise position on crop-based biofuels setting the cap for each country at the level reached in 2017 , and a radical position on the palm oil with an immediate phase-out in 2021.

The final compromise was reached by the co-legislators (Parliament and Council) in June 2018, eventually adopted in November and published by the Commission in December 2018.

\section{RED II targets and caps}

RED II provides overall targets for renewable energy, a specific support to "advanced biofuels" and electricity in transport, and a capping of crop-based biofuels.

The main dispositions are the following:

\subsection{A global and a transport target}

- An overall target of $32 \%$ for renewable energy in the energy mix (against $27 \%$ in the original proposal);

- a transport target of $14 \%$ (against no target in the Commission's proposal, and 10\% in RED I).

\subsection{Capping the crop-based biofuels}

\subsubsection{A cap of $7 \%$}

- A cap for crop-based biofuels is imposed in each Member State at 2020 consumption level plus 1 percentage point with a maximum of $7 \%$ - providing an optional minimum of $2 \%$ for countries that didn't reach $2 \%$ consumption in 2020 (the original proposal cut by half the current $7 \%$ cap to $3.8 \%$ ).

Nevertheless, Member States have options to lower the cap or differentiate feedstocks: 


\section{RED2 - The Final Compromise}

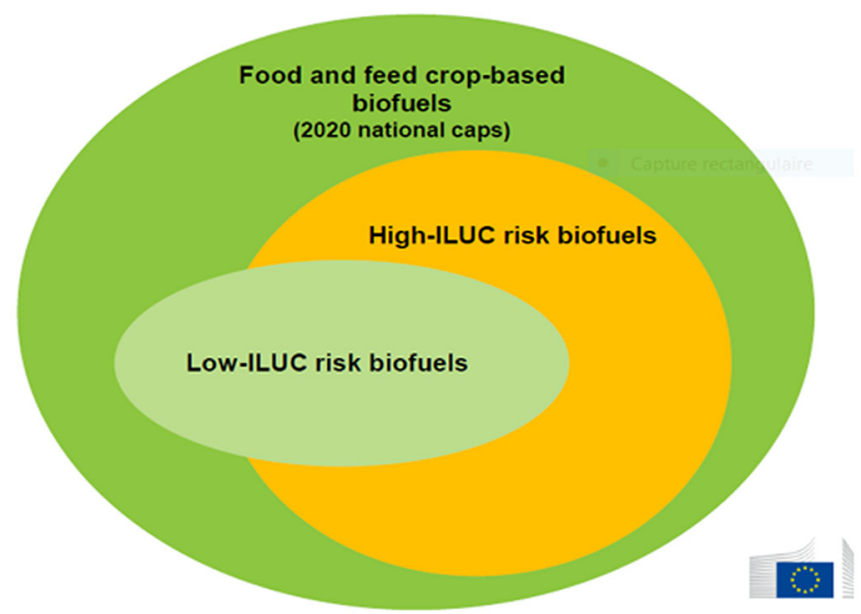

Fig. 1. High and low ILUC-risk feedstocks are accounted under the cap of food \& feed crops.

- proportionality option: for caps lower than 7\%, Member States can reduce proportionally the $14 \%$ transport target;

- ILUC differentiation option: based on ILUC figures (unchanged from RED II) Member states have the option to introduce different caps for the various crop-based biofuels (oil-feedstocks vs. starch or sugar);

\subsubsection{Phasing out high ILUC-risk feedstocks}

"High ILUC-risk feedstock" (such as palm oil) will be subject to a sub-cap (under the 7\% crop-based cap) at the 2019 consumption level from 2021 to 2023 and then phased-out to $0 \%$ by 2030 .

High ILUC-risk feedstocks are defined as those "for which a significant expansion of the production area into "land with high carbon stock" is observed (Fig. 1).

"Low ILUC-risk feedstocks" are exempted from this constraint. They are defined as additional feedstock causing no or minor ILUC as they result from productivity improvement (beyond what is expected without existence of the RED directive incentive) or produced on areas which were previously not used for cultivation of crops" (Fig. 1).

A Delegated Act requested by RED II from the Commission to define the feedstocks for which a significant expansion is observed, as well as the relevant criteria for low ILUC-risk certification.

These definitions will be reviewed and adjusted by June 2021 before the entry into force of the Directive, and at the occasion of the 2023 review.

\subsection{Targets and limitations within the $14 \%$ transport target}

Within the $14 \%$ transport target there are:

- a specific target for the advanced biofuels (Annex IX part A: lignocellulosic biofuels, algae...) of $3.5 \%$ in $2030(0.2 \%$ in $2022,1 \%$ in 2025);
- limitations for waste and residues (Annex IX part B: used cooking oils, animal fats) are set at $1.7 \%$ (option for Member States to set higher limit if they can prove the availability of the supply).

\subsection{Multipliers for accounting under the $14 \%$ target}

- feedstocks in both Annex IX part A \& part B may count double in the $14 \%$ target. Hence the effective use of advanced (part A) may be as low as $1.75 \%$ (3.5\%: 2) while the part B effective limitation may be as high as $3.4 \%$ $(1.7 \% \times 2)$;

- renewable electricity will count 4 times when used in road transport and 1.5 times in rail;

- renewable used in maritime and aviation may count 1.2 times.

\section{The sustainability criteria}

\section{$2.1 \mathrm{CO}_{2}$ savings}

Higher $\mathrm{CO}_{2}$ savings are required for the eligibility of biofuels depending of the date of the plants:

- Eligibility thresholds:

- $50 \%$ for installation in operation before Oct 2015;

- $60 \%$ after Oct 2015 ;

- $65 \%$ after 1 Jan 2021;

- $70 \%$ for electricity, heating \& cooling after 2021 and $80 \%$ after 2026;

- the fossil comparator has been raised to $94 \mathrm{~g} \mathrm{CO}_{2} / \mathrm{MJ}$ ( $v s$. $83.8 \mathrm{~g} \mathrm{CO}_{2} / \mathrm{MJ}$ in $\left.\mathrm{RED} \mathrm{I}\right)$.

\subsection{Environmental criteria}

Like in RED I, biofuels must not be produced from raw materials originating from: 
- high biodiversity land as of January 2008;

- high carbon stock land that changed use after 2008;

- land that was peatland in January 2008.

The RED II introduces new sustainability criteria for forestry feedstocks:

- harvesting takes place with legal permits, not exceed the growth rate of the forest;

- biofuels and bioenergy from forest materials must comply with requirements which mirror the principles contained in the EU LULUCF regulation.

\section{Form of support in Member States}

Member States are free to choose the most suitable form of support for renewables in transport, for example volume mandates, energy mandates or GHG emission savings targets.

While most countries have chosen national blending mandates, Germany has introduced a different kind of support through the introduction of "GHG quota" targets in 2015. RED II will allow these different schemes to co-exist.

\section{Timing of implementation and reviews}

"National Energy and Climate Plan" (NECP) due by each Member State must present a trajectory to reach RED II targets. The Commission verifies that the NECPs lead to fulfilling the overall EU targets. Draft NECPs have been presented in 2018, the final versions must be sent by end of 2019.

Transposition of RED II by Member States is due by June 31st, 2021.

In 2023: mid-term review:

- both the $32 \%$ overall target and the transport $14 \%$ subtarget may be increased (and not decreased);

- definition of the trajectory for the elimination to $0 \%$ in 2030 for high ILUC-risk. Eventual modification of high and low ILUC-risk.

In 2026 Commission's proposal for the post 2030 Renewable Energy policy (RED III).

\section{Appendix A High and low ILUC risk: The Delegated Act on high and low ILUC-risk biofuels (EU 2019/807-13th March 2019)}

\section{High ILUC-risk biofuels}

High ILUC-risk fuels are those "produced from feedstock with a significant expansion into land with high carbon stocks" with the following cumulative conditions:

- the global production area of the feedstock has increased annually by more than $1 \%$ and 100000 hectares after 2008 .

- more than $10 \%$ of such expansion has taken place on land with high carbon stock.
The expansion is calculated with a formula which takes into account factors that influence the amount of GHG emissions:

$$
x_{h c s}=\frac{x_{f}+2.6 x_{P}}{\mathrm{PF}},
$$

where, $x_{h c s}=$ share of expansion into land with high-carbon stock; $x_{f}=$ share of expansion into land referred to in Article 29 (4)(b) and (c) of Directive (EU) 2018/2001; $x_{P}=$ share of expansion into land referred to in Article 29(4)(a) of Directive (EU) $2018 / 2001$ including peatland; $\mathrm{PF}=$ productivity factor.

PF shall be 1.7 for maize, 2.5 for palm oil, 3.2 for sugar beet, 2.2 for sugar cane and 1 for all other crops.

An Accompanying Report (COM 2019-142 final) provides the data on which are based ( $c f$. Tab. 1).

The $10 \%$ expansion on high $\mathrm{C}$ land level over which a feedstock is classified as high ILUC-risk. This level is set as to ensure that the emissions from land use change on high $\mathrm{C}$ land doesn't negate the direct savings resulting from the fossil fuel replacement by the biofuel. The report evaluates ${ }^{1}$ it at $14 \%$.

The expansion on high carbon stocks for several feedstocks.

According to the report data, and the formula, only palm oil with an expansion figure of over $40 \%$ is classified as high ILUC, while Soybean (with 8\%), Corn (with 2.4\%), and Sugar Cane (with 2.3\%), although expanding on forestland are under the $10 \%$ threshold.

\footnotetext{
${ }^{1}$ Accompanying Report (Page 12: Box 2: The impact of indirect land use change on biofuel GHG emission savings).

If land with high stocks of carbon in its soil or vegetation is converted for the cultivation of raw materials for biofuels, some of the stored carbon will generally be released into the atmosphere, leading to the formation of carbon dioxide $\left(\mathrm{CO}_{2}\right)$. The resulting negative greenhouse gas impact can offset the positive greenhouse gas impact of the biofuels or bioliquids, in some cases by a wide margin.

The full carbon effects of such conversion should therefore be taken into consideration for the purpose of indentifying the level of significant feedstock expansion into land with high carbon stock resulting from biofuel demand. This is necessary to ensure that biofuels lead to greenhouse gas emission saving. Using the results of the GIS assessment, the average net loss of carbon stock when biofuel feedstock replaces land with high carbon stock 23 can be estimated in about 107 tonnes of carbon (C) per hectare24. Spread over 20 years, that amount is equivalent to a yearly emission of 19.6 tons of $\mathrm{CO}_{2}$ per hectare.

It should be noted that the GHG emissions savings also depend on the energy content of the feedstock produced on the land each year. For annual crops, except maize and sugar beet, the energy-yield can be estimated at about $55 \mathrm{GJ} / \mathrm{ha} / \mathrm{y} 26$. By combining both figures one can estimate the land use change emissions associated to biofuels production on deforested land at around $360 \mathrm{~g} \mathrm{CO}_{2} / \mathrm{MJ}$. By comparison, the emissions savings resulting from replacing fossil fuel with biofuels produced from these crops can be quantified in about $52 \mathrm{gCO}_{2} / \mathrm{MJ} 27$.

Given these assumptions, it can be estimated that the land use change emissions will negate the direct GHG savings resulting from fossil fuel replacement when biofuel crop expansion into land with highcarbon stock reaches a share of $14 \%\left(52 \mathrm{~g} \mathrm{CO}_{2} / \mathrm{MJ} / 360 \mathrm{~g} \mathrm{CO}_{2} /\right.$ $\mathrm{MJ}=0.14)$.
} 
Table 1. Feedstock expansion on high carbon land. (Source: Commission Delegated Regulation (EU) 2019/807 of 13 March 2019).

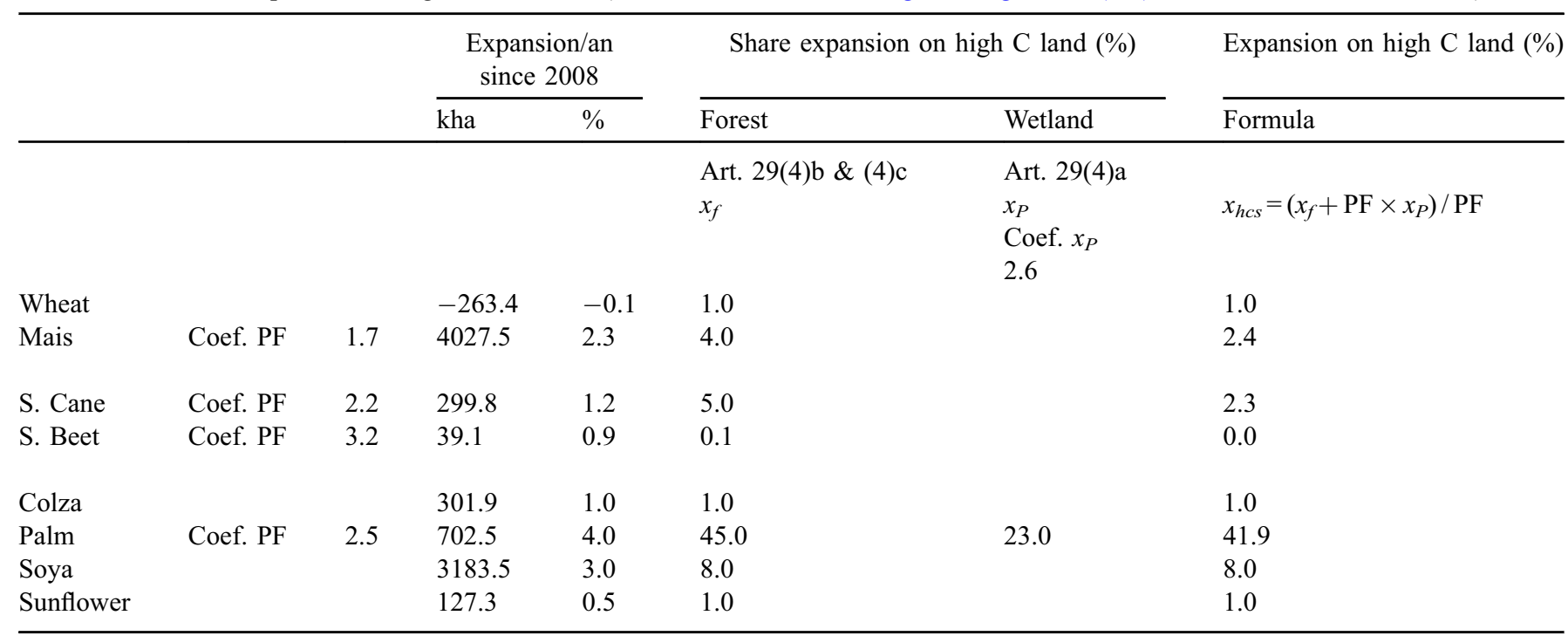

\section{Low ILUC-risk biofuels}

As explained by the Commissioner Cañete: "Fuels are considered as low ILUC-risk only if produced from additional feedstock produced on a delineated area that is the direct result of applying an additionality measure. Only measures that are financially attractive because they allow to reap the financial premium arising from such certification are eligible and eligibility of measures is limited to a period of 10 years."

There is an exemption to prove the financial criterion:

- for the small holders (cultivating on less than 2 ha and being independent from big plantations);

- as well as for the production coming from abandoned and degraded land;

- the certification of low-ILUC-risk will be audited by voluntary schemes.

\section{Monitoring and review of the Delegated Act}

"The Commission will by June 30th, 2021 review all relevant aspects of the report on feedstock expansion, in particular the data on feedstock expansion, as well as the evidence on the factors justifying the smallholders' provision, and, if appropriate, amend this Regulation. This revised report shall be submitted to the European Parliament and the Council and become the basis for the application of the criteria set out in Article 3."

The Commission shall review thereafter the data included in the report considering evolving circumstances and latest available scientific evidence:

- a further review of the criteria set out in this Delegated Act is foreseen by the RED II for September 1st, 2023.

- an implementing act laying out the details for certification of low ILUC-risk biofuels is currently under preparation by the Commission and is expected to be published before 2021 .

\section{The Delegated Act is criticized by all sides-by palm producers as well as by anti-palm NGOs}

The Delegated Act on ILUC-risk biofuels was closely followed and harshly debated with radically opposite views on the one hand by the palm oil producing countries and by the NGO and the EU Agricultural Organisations on the other.

Palm oil producing countries (Indonesia, Malaysia, Columbia) have declared that they will file a complaint before the WTO.

Environmental NGOs, after a strong lobby to strengthen the conditions of the "low ILUC-risk exemption" are still not satisfied by the fact that soybean is not classified as high ILUC-risk.

EU agricultural producers see in the ILUC-risk approach as a positive move as it cuts the link between crop-based biofuels and the deforestation, putting the pressure on feedstocks directly responsible, and allowing for a mitigation of ILUC overall. Nevertheless, they are still concerned by the exemptions of the low ILUC-risk as they see many loopholes which may allow high ILUC-risk coming by the back door.

The EU Commission, under the diplomatic pressure of South-East Asian Countries, has always been reluctant to take too strong a stance against palm oil use in biofuels. It is only under the pressure of the European Parliament and obliged by the political agreement reached by the colegislator, that the Commission delivered the regulation set by the Delegated Act.

\section{Appendix B Palm: a controversial feedstock}

\section{The palm issue}

\subsection{ILUC: the palm oil expansion is responsible for the ILUC figures of all other vegetable oils biofuels}

The palm oil issue has constantly negatively impacted the debate on biodiesel and vegetable oil use as feedstock for 
bioenergy. The very rapid development of the palm oil production in South-East Asia, is associated with important GHG emissions as it is linked to a rapid and very significant deforestation, occurring for $50 \%$ on peatland releasing high quantities of $\mathrm{CO}_{2}$ in the atmosphere. Furthermore, the loss of biodiversity from the destruction of the primary forest by expanding palm oil plantations leads to more criticism.

Although the expansion of the palm production is driven by the demand for food, and that less than $20 \%$ is used for energy in the world (13 million tons vs. 74 million tons total production), the high carbon impact of the palm oil expansion weighs on ILUC figures of all other vegetable oil. The "indirect emissions" accounted in the ILUC econometric model for vegetable oils used for bioenergy are based on the assumption that it must be replaced on the world food market by an increased palm oil production. In the various ILUC models, the palm oil very high GHG emissions explain that ILUC figures of all other vegetable oils biofuels are higher than those of other biofuels feedstocks as starch and sugar (used for ethanol).

Nevertheless, concerning rapeseed biodiesel, even with the indirect burden from palm oil on its own ILUC figures, the most recent models (GTAP and Globiom) find ILUC figures for rapeseed biodiesel that are 4 to 5 times lower than that of palm oil (Fig. 2).

\section{Estimates ILUC emissions}

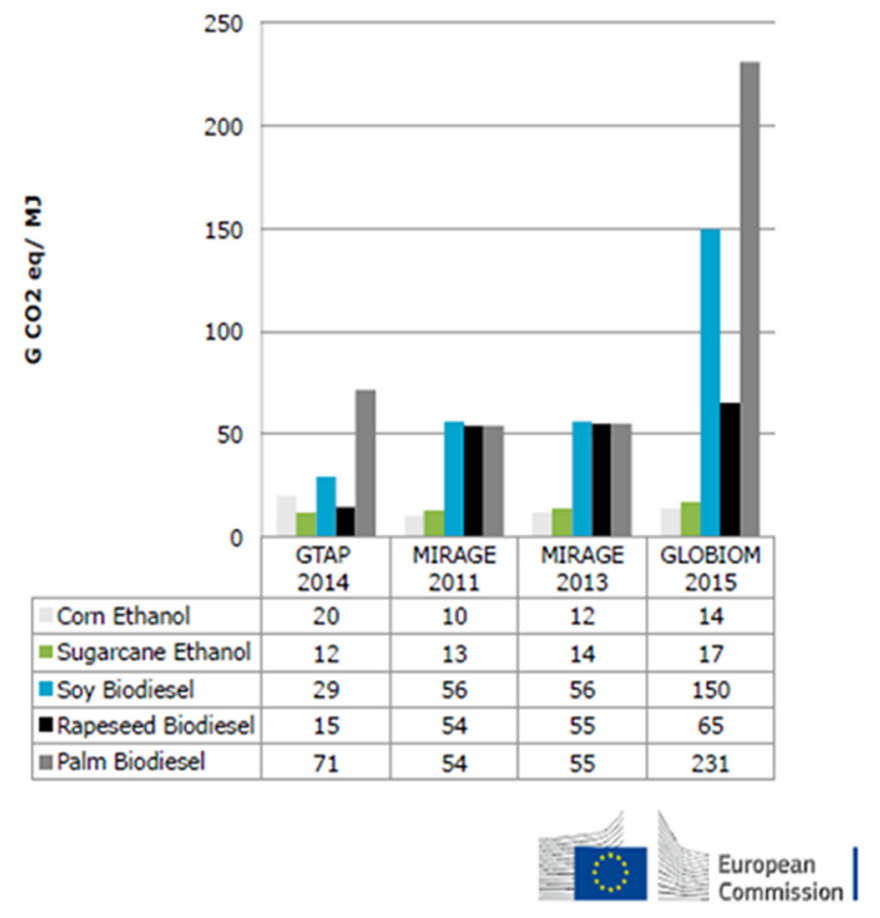

Fig. 2. ILUC emissions - Various models results by feedstocks.

What's more, the Globiom study has shown that the deforestation and peatland drainage was responsible for almost the entire ILUC: a simulation on the "Energy mix 2020 " shows an global ILUC figure reduced from $97 \mathrm{~g} \mathrm{CO}_{2} /$
Table 2. ILUC models results for Energy mix 2020 for various scenario.

\begin{tabular}{lll}
\hline Scenario & $\begin{array}{l}\text { Globiom } \\
\left(\mathrm{g} \mathrm{CO}_{2} / \mathrm{MJ}\right)\end{array}$ & $\begin{array}{l}\text { IFPRI } \\
\text { Mirage }\left(\mathrm{g} \mathrm{CO}_{2} / \mathrm{MJ}\right)\end{array}$ \\
\hline Energy mix 2020 & 97 & 38 \\
Deforestation & 87 & \\
Low & 48 & \\
Very low & & \\
No peatland drainage & 4 & \\
+ very low deforestation & & \\
\hline
\end{tabular}

$\mathrm{MJ}$ to $4 \mathrm{~g} \mathrm{CO}_{2} / \mathrm{MJ}$ if there were no peatland drainage and the deforestation rate were low (Tab. 2).

\section{Palm oil use in the EU biodiesel production has been growing these last 5 years, linked to development of HVO capacities}

Another issue with the palm oil use in EU biofuels is although it is yet by far not the major feedstock, its share has been increasing over the latter years: every increase of the EU biodiesel since 2015 has been via palm oil use.

This is linked to the development of the technology of hydrotreated vegetable oil (HVO) through investments generally made by the major Oil Companies.

While classical biodiesel produced with the "esterification process" (vegetable oil methyl ester) doesn't allow for using more than an EU level average of 15 to $20 \%$ of palm oil for quality issue (winter grade-the palm turning solid at low winter temperature"), the HVO eliminates this constraint as the process ( under high temperature and pressure) produces a fuel similar to fossil fuel.

The development of HVO plant capacities, which may use indistinctly any vegetable oil, and hence run on lower priced palm oil and palm oil products (PFADs), triggered an increased quantities of palm oil and products in biofuels (biodiesel and bioethanol) with a share raising from $15 \%$ to $25-30 \%$ of the total in a few years (Fig. 3) .

\section{The new approach of ILUC through "ILUC-risk biofuels" will help to mitigate ILUC overall and improve the sustainability of biofuels}

Moving from an ILUC concept to an ILUC risk feedstock approach puts the pressure on the very source of the ILUC. It will encourage the palm producing countries to improve the sustainability of their palm production, and act against deforestation. 


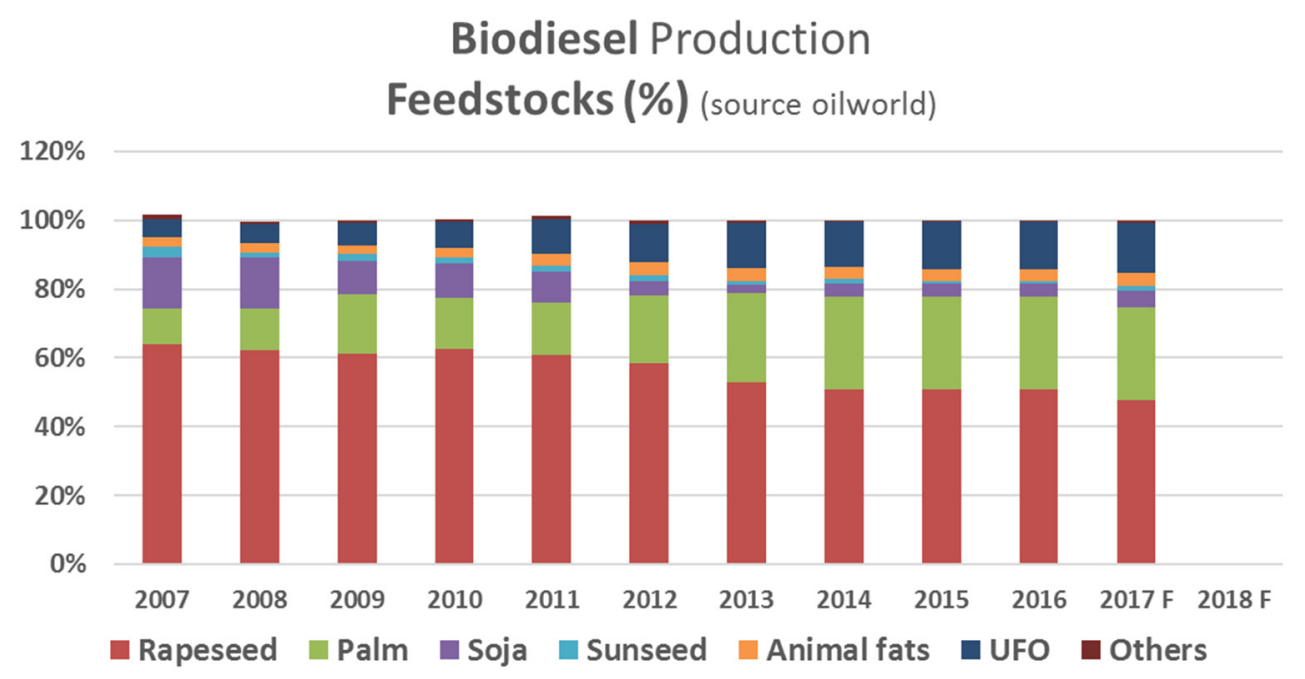

Fig. 3. Feedstock shares in EU biodiesel. (Source: Oilworld).

\section{Appendix C EU Biodiesel: originally an alternative to mandatory set aside and a way to unlocking the production of local protein}

\section{The history of biodiesel in the EU: how did everything start?}

- 1992: EU mandatory set-aside in the framework of the Common Agriculture Policy (CAP) to address agricultural production surplus and regularly depressed global prices; the non-food production on these set-aside lands allowed the production of proteins and biodiesel to reduce the need to import it, maintaining the producer's revenues while simultaneously controlling the supply of cereals;

- 2003: Directive 2003/30/EC on the promotion of biofuels, setting a voluntary objective of $5.75 \%$ renewable energy in transport for 2010 ;

- 2003: Directive 2003/96/EC restructuring the taxation of energy products and electricity, giving a common EU legal basis for the tax exemptions for biofuels (although limited in time up to 2020) - especially important for Germany's restructuring of its own national legislation;

- 2009: RED I (2009/28/EC) the Renewable Energy Directive, setting a $10 \%$ target of renewable energy in transport for 2020, aiming at reducing GHG emissions, enhancing EU Energy independence and supporting the EU agricultural sector;

- 2013-2015: debate around the ILUC Directive (2015/ 1513/EC) which impacted negatively the perception of the biofuel sector and led to a shift in the European biofuel policies towards advanced biofuels and electrification. EU production did not progress since then. Crop-based biofuels have been capped at $7 \%$ in all member states;

- 2016-2018: debate on the recast of the Renewable Energy Directive is dominated by the palm oil issue.
RED II (2018/2001/EC) compromise allows for stabilisation of biodiesel and plans the elimination of palm oil by 2030. After intense negotiations, the cap of crop-based biofuels for each member state is maintained at the consumption level of 2020 , with a maximum of $7 \%$, allowing the prospect of a stabilisation of biodiesel.

The debates on ILUC as well as on palm oil are concluded by the introduction of a category of ILUC-risk feedstocks defined as those with a significant expansion on high carbonstock land which will be progressively eliminated by $2030-$ a Delegated Act has determined that palm oil as the only feedstock classified as such. RED II thus cuts the link of cropbiofuels with the deforestation and effectively mitigates the risk of ILUC.

In parallel, the only targets provided by RED II are specifically directed at second generation biofuels and electricity, confirming the direction of the energy policy toward advanced biofuels and e-mobility.

\section{Appendix D Biodiesel-EU Rapeseed-EU's protein deficit}

\section{The bioenergy outlet is crucial for the EU oil and protein sector-and specially for EU rapeseed}

Rapeseed is the major oilseed involved in bioenergy, as around $70 \%$ of EU rapeseed oil is used in biodiesel production (Fig. 4).

Today, the production of the rapeseed is closely linked to the demand for biodiesel which historically has supported the growth of EU rapeseed area: from the early 1990's with the cultivation on "set-aside", to the blending mandates introduced since the mid 2010's that triggered a doubling of the rapeseed production since 2004 (Fig. 5). 


\section{Biodiesel $=$ outlet for $70 \%$ of EU Rapeseed Oil}

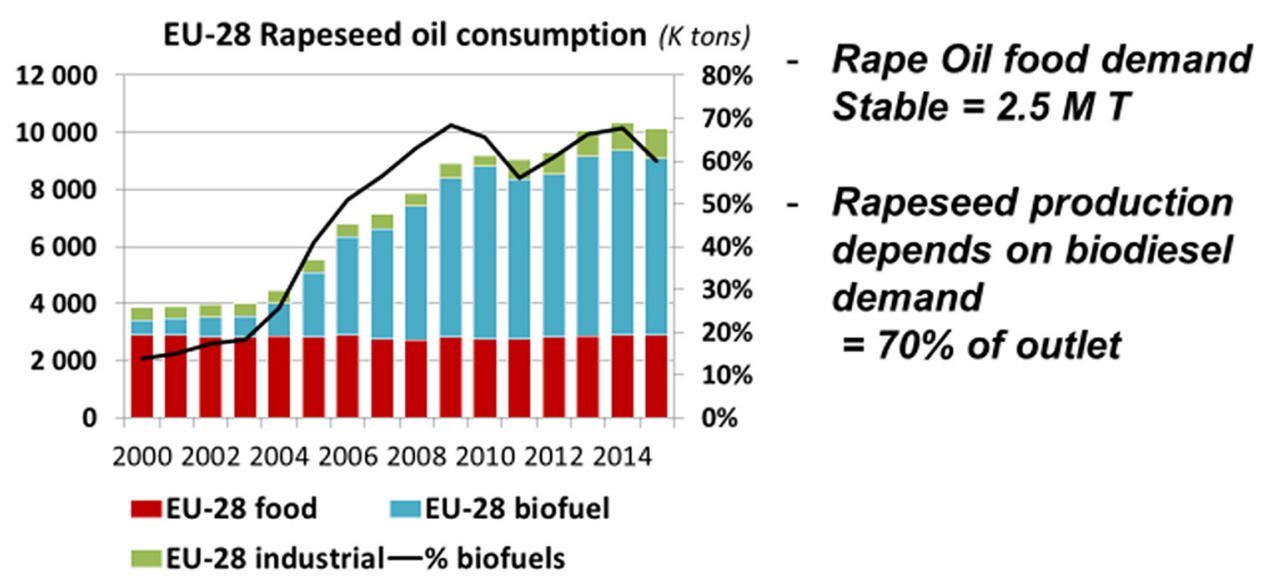

Fig. 4. Rapeseed oil use in food, biodiesel \& industry EU 28. (Source: Oil World \& Avril).

\section{Rapeseed area : up 60\% to meet rising biodiesel demand}

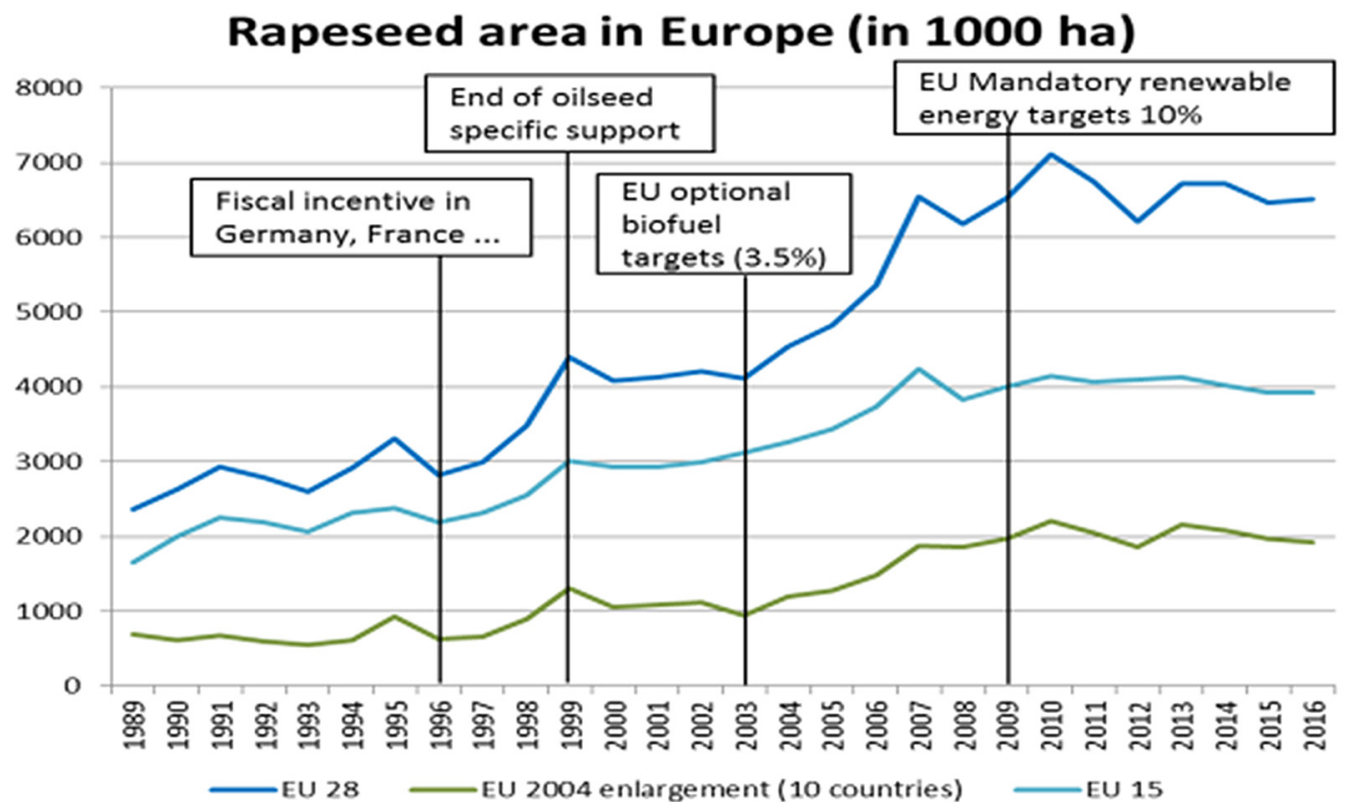

Fig. 5. Rapeseed area evolution in EU28, in former \& new Member States. 


\section{Rapeseed meal : co-produced from biodiesel - crucial to reduce EU protein dependence on imports}

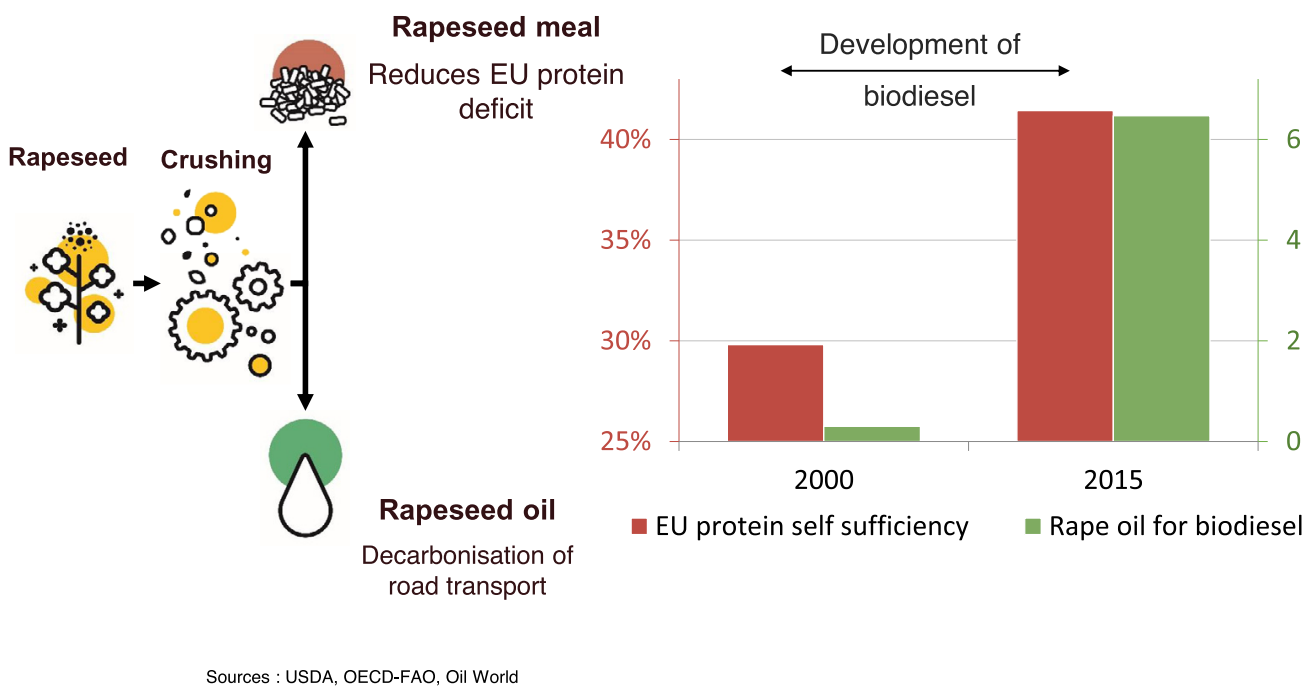

Fig. 6. EU rapeseed biodiesel vs. EU protein imports.

It is important to underline the protein co-production linked to the development of the rapeseed production (around $60 \%$ of rapeseed meal co-produced for $40 \%$ rapeseed oil), and to remember the major contribution of rapeseed and other oilseeds to mitigating the EU protein deficit (Fig. 6).

\section{Appendix E Rapeseed biodiesel: a major contribution to the Renewable Energy in EU}

According to the 2019 Renewable Energy Progress report (COM 2019-225 final), in 2016 biodiesel represented $80 \%$ of the renewable energy from biofuels consumed in the European Union (11 Mtoe vs. 13.8 Mtoe). As vegetable oils in 2016 made up to around $70 \%$ of it, and used cooking oil and animal fats another $26 \%$, rapeseed oil was still the major feedstock with around $45 \%$, while palm oil reached $20 \%$ (to which could be added palm products as PFAD not clearly registered for around $5 \%$ to $7 \%$ ) and soy oil for less than $5 \%$.

\section{References}

Accompanying Report. 2019. COM(2019) 142 final: Report on the status of production expansion of relevant food and feed crops worldwide. Available from https://ec.europa.eu/transparency/regdoc/rep/1/2019/ EN/COM-2019-142-F1-EN-MAIN-PART-1.PDF.

Delegated Act Commission Delegated Regulation (EU) 2019/807. 2019. Commission Delegated Regulation (EU) 2019/807 of 13 March 2019 supplementing Directive (EU) 2018/2001 of the
European Parliament and of the Council as regards the determination of high indirect land-use change-risk feedstock for which a significant expansion of the production area into land with high carbon stock is observed and the certification of low indirect landuse change-risk biofuels, bioliquids and biomass fuels. Available from http://data.europa.eu/eli/reg_del/2019/807/oj.

Directive 2003/30/EC. 2003. Directive 2003/30/EC of the European Parliament and of the Council of 8 May 2003 on the promotion of the use of biofuels or other renewable fuels for transport. Available from https://eur-lex.europa.eu/legal-content/EN/TXT/ $\mathrm{PDF} /$ ?uri $=$ CELEX:32003L0030\&from=EN.

ILUC Directive (EU) 2015/1513. 2015. Directive (EU) 2015/1513 of the European Parliament and of the Council of 9 September 2015 amending Directive 98/70/EC relating to the quality of petrol and diesel fuels and amending Directive 2009/28/EC on the promotion of the use of energy from renewable sources (Text with EEA relevance). Available from https://eur-lex.europa.eu/ legal-content/EN/TXT/?uri=CELEX\%3A32015L1513.

RED II - Directive (EU) 2018/2001. 2018. Directive (EU) 2018/2001 of the European Parliament and of the Council of 11 December 2018 on the promotion of the use of energy from renewable source. Available from https://eur-lex.europa.eu/legal-content/ EN/TXT/?uri=uriserv:OJ.L .2018.328.01.0082.01.ENG.

The Renewable Energy Directive (2009/28/EC-RED I). 2009. Directive 2009/28/EC of the European Parliament and of the Council of 23 April 2009 on the promotion of the use of energy from renewable sources and amending and subsequently repealing Directives 2001/77/EC and 2003/30/EC (Text with EEA relevance). Available from https://eur-lex.europa.eu/LexUr iServ/LexUriServ.do?uri=OJ:L:2009:140:0016:0062:en:PDF.

Cite this article as: Dusser P. 2019. The European Energy Policy for 2020-2030 RED II: what future for vegetable oil as a source of bioenergy?. OCL 26: 51. 